\section{Roy Markham}

THE DEATH of Professor Roy Markham, Director of the John Innes Institute, on 16 November 1979 has deprived us of a scientist who made outstanding contributions to research in several quite different experimental fields. He was born in London on 29 January 1916, the son of A.C.C. Markham, and educated at St Paul's School. In 1935 he entered Christ's College, Cambridge and read biochemistry for Part II of the tripos. After graduation in 1938 he decided on a research career, joining N.W. Pirie in the biochemistry department. In 1940 he joined Kenneth M. Smith at the Plant Virus Research Station which was then under the auspices of the Ministry of Agriculture.

By modern laboratory standards the available facilities at the Plant Virus Research Station were very primitive. They consisted of a few glasshouses and part of a wooden potato storage shed which had neither heating nor running water. However, they were fortunate enough to be allowed to continue making use of a room as a laboratory at the top of the Molteno Institute, previously allocated to Professor David Keilin. In this room, together with some additional facilities made available on the Downing site, Roy Markham laid the foundations for his later achievements. By 1942 he had already developed a steam distillation apparatus suitable for microKjeldahl analysis which was subsequently listed under the British Standards Institute B.S. 1428 .

In 1940 Kenneth Smith was working with a new plant virus (turnip yellow mosaic) which was shown to have several interesting properties. Roy Markham became particularly interested in the physico-chemical properties of this and other small plant virus particles which stimulated his interest in the problem of high speed centrifugation. He had a genius for improvising and was highly skilled in making his own apparatus from bits and pieces found in the laboratory. An air driven high speed centrifuge was one of the devices he constructed to isolate virus particles.

It was soon realised that highly concentrated virus suspensions could be produced with a high speed centrifuge, and it was relatively easy to purify the virus with ethanol and half saturated ammonium sulphate. These highly concentrated suspensions led to the formation of octagonal crystals and this virus was one of the first (if not the first) insect-transmitted (flea beetle) viruses to be crystallised.

A number of important results emerged from these early experiments; it was shown that turnip yellow mosaic virus could be separated into two fractions which were named "top" and "bottom" components. At the time there was considerable controversy concerning the presence of nucleic acid and its significance in virus particles, but Roy Markham clarified the issue by establishing that the "bottom" component containing the RNA was highly infectious whereas the "top" component devoid of the nucleic acid was noninfectious.

In 1945 the research came under the aegis of the Agricultural Research Council and the Plant Virus Research Unit was established. Roy Markham became increasingly involved with the physiocochemical properties of plant viruses. Kenneth Smith concentrated more on the biology, ultrastructure and transmission of plant and insect viruses. However, Roy Markham, together with Ellis Cosslett were among the first investigators to record electron micrographs of plant virus microcrystals.

He will be particularly remembered for his work on viruses when he was joined by J.D. Smith and R.E.F. Matthews. They formed a most fruitful collaboration, producing a series of important publications which established the composition and properties of several plant viruses. He was elected Fellow of the Royal Society at the early age of forty.

His interest in electron microscopy started when examining air-dried and unstained samples of viruses in an early RCA machine which was installed in the Cavendish Laboratory. Although many biologists were highly critical of the images produced from early studies in electron microscopy, Roy Markham quickly realised the powerful potential of applying these instruments to the structure and measurement of virus particles. When the Plant Virus Research Unit was fully established at the University Farm in Huntingdon Road, Cambridge, the laboratory possessed one of the first production electron microscopes. In addition, extensive research facilities were made available with the aid of various grants Roy Markham had obtained in support of the expanding virus research programme.

Kenneth Smith retired in 1959 and Roy Markham became Director of the Plant Virus Research Unit. The work continued to expand and a regular flow of visiting scientists came to his laboratory. His interest and enthusiasm for developing and building apparatus gathered momentum as war surplus equipment continued to provide an ideal source of materials. The symmetry associated with the architecture of virus particles together with their repeating features stimulated him to construct a device which allowed the regular structural features of viruses recorded in electron micrographs to be averaged and subsequently reinforced. The technique was established as the "Markham averaging method". In addition he investigated the potential of image analysis by building a simple ultraviolet light optical diffractometer for recording the diffraction spectra from electron micrographs and making accurate measurements.

There will be very many visitors to the Plant Virus Research Unit at Cambridge who will remember the warm welcome and hospitality they received from Roy and Margaret (née Mullen whom he married in 1940), who enjoyed entertaining their guests in a most elegant style. Roy Markham had a lighted-hearted approch to research, coupled with an infectious sense of humour which visitors from abroad found difficult to appreciate on first impression, and it must be said led to some misunderstanding on more than one occasion.

In 1967 the Directorship of the John Innes Institute fell vacant at a time when a decision had been made to move the institute from Bayfordbury in Hertfordshire to Norwich. Roy Markham was invited to fill the post, and saw an opportunity to create an unique centre for research by proposing that an institute could be established by moving the Plant Virus Research Unit in Cambridge to form part of the John Innes Institute at Norwich. This resulted in a considerable undertaking, as Roy Markham became involved in the planning of a large complex of laboratories and ancilliary services. The John Innes Institute brought together under Roy Markham's Directorship and guidance during a period of just over ten years, has been re-established as a centre of international standing.

It is characteristic of Roy Markham that he left little record of his life, apart from his collection of scientific and administrative material. Although he had relatively few interests outside the laboratory, he devoted a great deal of his spare time at home to designing and constructing experimental apparatus for people within the institute. During his long illness he persisted until the end in working on a second and more advanced device for the processing of electron microscope images with the aid of computers.

R. W. Horne 